\title{
New Aromatic Nitro Compounds from Salegentibacter sp. T436, an Arctic Sea Ice Bacterium: Taxonomy, Fermentation, Isolation and Biological Activities
}

\author{
Wael Al-Zereini, Imelda Schuhmann, Hartmut Laatsch, Elisabeth Helmke, \\ Heidrun Anke
}

Received: February 2, 2007 / Accepted: April 9, 2007

(C) Japan Antibiotics Research Association

\begin{abstract}
Nineteen aromatic nitro compounds were isolated from the culture broth of an Artic sea ice bacterium. Four of these compounds are new and six compounds are reported from a natural source for the first time. The new natural products showed weak antimicrobial and cytotoxic activities. 2-Nitro-4-(2'-nitroethenyl)-phenol was the most potent antimicrobial and cytotoxic substance. Some of the compounds exhibit plant growth modulating activities. Based on its biochemical properties and the $16 \mathrm{~S}$ rRNA gene sequence, the producing strain can be described as a distinct species within the genus Salegentibacter.
\end{abstract}

Keywords marine bacteria, aromatic nitro compounds, antibacterial activity, cytotoxic activity, Salegentibacter

\section{Introduction}

The marine environment represents a rich source of living organisms and concomitant with this biodiversity a high chemical diversity of marine natural products is found. Lately marine bacteria have roused interest due to their unique secondary metabolites which differ significantly from the ones produced by terrestrial counterparts [1, 2]. During our screening for metabolites with antimicrobial activities, Salegentibacter sp. T436 was found to produce a large number of aromatic nitro compounds, some of which have antimicrobial and cytotoxic activities.

In this paper we report the taxonomy of strain T436, its fermentation, the isolation and purification of the compounds based on bioactivity-guided fractionation, as well as their biological activities. The physico-chemical and chemical structures will be reported in a separate paper [3].

\section{Materials and Methods}

Producing Organism

The Salegentibacter strain T436 was derived from a bottom section of a sea ice floe collected from the Arctic Ocean [4] during the cruise of R.V. Polarstern, ARKXIII/2. It has been deposited in the collections of the Alfred-WegenerInstitute and the Institute of Biotechnology and Drug Research (IBWF), Germany.

\section{Taxonomic Studies}

Morphological, Biochemical, and Physiological Tests

Morphological studies were carried out using a light microscope and a phase contrast microscope on cultures grown for $3 \sim 4$ days at $22^{\circ} \mathrm{C}$ on modified LB agar medium (50\% marine LB agar medium).

Biochemical and physiological characteristics were determined using standard procedures $[5,6]$. Production of acid from different carbohydrates, utilization of organic

I. Schuhmann, H. Laatsch: Institute of Organic and Biomolecular Chemistry, University of Göttingen, Tammannstrasse 2, D-37077 Göttingen, Germany

E. Helmke: Alfred-Wegener-Institute for Polar and Marine Research, Am Handelshafen 12, 27570 Bremerhaven, Germany
H. Anke (Corresponding author), W. Al-Zereini: Institute for Biotechnology and Drug Research (IBWF), Erwin-SchrödingerStrasse 56, D-67663 Kaiserslautern, Germany,

E-mail: anke@ibwf.de 
compounds as sole carbon or nitrogen sources were determined by the method of Helmke \& Weyland [7].

Sequencing and Analysis of 16S rDNA

Extraction of genomic DNA was carried out on $2.0 \mathrm{ml}$ of a well-grown culture in modified LB medium by following the method described by Süßmuth et al. [6] with some modifications. For polymerase chain reaction (PCR), $100 \sim 300 \mathrm{ng}$ of extracted DNA was added to $50 \mu \mathrm{l}$ of a reaction mixture containing $1 \mathrm{U}$ of Taq polymerase (MBI Fermentas, St. Leon, Germany), dNTP mixture ( $400 \mu \mathrm{M}$ of each type), 1 pmol of primers 16SA (5'-AGAGTTTGATCCTGGCTC) and 16SB (5'-AAGGAGGTGATCCAGCCGCA), $4 \mathrm{mM}$ magnesium chloride, and PCR buffer with ammonium sulfate. The primers were synthesized by MWG-biotech (Ebersberg, Germany). Amplification was done by an initial denaturation period of 3 minutes at $94^{\circ} \mathrm{C}$, 30 cycles of denaturation at $94^{\circ} \mathrm{C}$ for 30 seconds, annealing at $55^{\circ} \mathrm{C}$ for 30 seconds, and extension at $72^{\circ} \mathrm{C}$ for 30 seconds, with a final extension period of 10 minutes. The PCR product $(\sim 1500 \mathrm{bp})$ was detected by electrophoresis [8] and purified with a NucleoSpin ${ }^{\circledR}$ extraction kit (Macherey \& Nagel, Düren, Germany) following the manufacturer's instructions. The 16S rRNA gene sequence was compared with those available in the GenBank and Ribosomal database project II (RDP).

\section{Fermentation}

Salegentibacter sp. T436 was cultured in 500-ml Erlenmeyer flasks containing $250 \mathrm{ml}$ of modified LB medium composed of yeast extract $0.5 \%$, tryptone $0.5 \%$, $\mathrm{NaCl} 1.0 \%$ in half strength artificial sea water, $\mathrm{pH}$ 7.2. Half strength artificial sea water was prepared by dissolving $16.7 \mathrm{~g}$ of marine salt mixture, purchased from Tropic marine $^{\circledR}$ (Dr. Biener, Wartenberg-Germany), in 1 liter distilled water. The incubation was carried out on a rotary shaker $(121 \mathrm{rpm})$ at $21^{\circ} \mathrm{C}$ for 48 hours. This culture was used to inoculate a Biolafitte $\mathrm{C} 6$ fermentor containing 20 litres of B1-medium (A-Z amine $0.25 \%$, beef extract 3.8\%, soy meal $0.1 \%$, yeast extract $0.25 \%$, seaweed extract $0.25 \%$ (v/v), marine salts mixture $3.33 \%$, adjusted to $\mathrm{pH} 8.0$ ). The fermentations were carried out at $21^{\circ} \mathrm{C}$ with aeration of 3.0 litres/minute and agitation of $121 \mathrm{rpm}$.

During the fermentation process, daily samples $(150 \sim 200 \mathrm{ml})$ were taken and the culture fluid was separated from the bacterial cells by centrifugation $(16000 \mathrm{~g}, 10$ minutes). The supernatant was adjusted to $\mathrm{pH}$ 4 and extracted with an equal volume of EtOAc. The organic phase was dried over $\mathrm{Na}_{2} \mathrm{SO}_{4}$, concentrated in vacuo at $40^{\circ} \mathrm{C}$ and the resulting residue was dissolved in $\mathrm{MeOH}$ to a final concentration of $10 \mathrm{mg} / \mathrm{ml}$. Aliquots corresponding to $300 \mu \mathrm{g}$ of the concentrated residue were used for the evaluation of the antifungal and antibacterial activities in the agar diffusion assay using Nematospora coryli and Bacillus brevis as test organisms.

\section{Analysis of the Fermentation Samples}

Growth was monitored by OD measurement at $580 \mathrm{~nm}$ ( $1: 10$ diluted culture fluid) and the increase in colony forming units (cfu). The changes in the metabolite spectrum were monitored by analytical HPLC using $75 \mu \mathrm{l}$ samples (RP-18, LiChroCart ${ }^{\circledR}, 5.0 \mu \mathrm{m}, 125 \times 4 \mathrm{~mm}$; flow: $1.0 \mathrm{ml} /$ minute; gradient: $0.1 \% \mathrm{H}_{3} \mathrm{PO}_{4}-\mathrm{MeCN} 1 \sim 100 \%$ in 20 minutes).

\section{Isolation and Purification of the Compounds}

After 115 137 hours of fermentation in B1 medium, when the OD started to decrease and/or the antimicrobial activity had reached its maximum, the cultures were harvested. The fluid was centrifuged; the supernatant was adjusted to $\mathrm{pH} 4$ and extracted with EtOAc. After drying with $\mathrm{Na}_{2} \mathrm{SO}_{4}$, the organic phase was concentrated. The combined crude extracts from three 20 litres fermentations $(8.97 \mathrm{~g})$ were applied onto a silica gel column (Merck 60, 0.063 0.2 $\mu \mathrm{m}$; column $7 \times 18 \mathrm{~cm})$. Elution with cyclohexane - EtOAc $(1: 1)$ yielded $1.21 \mathrm{~g}$ of active fraction. Further purification of this fraction by repeated chromatography on silica gel (column size $2.5 \times 20 \mathrm{~cm}$ ) gave rise to two active fractions $\mathrm{A}$ and $\mathrm{B}$ : fraction A $(31.2 \mathrm{mg})$ was eluted with cyclohexane - EtOAc $(3: 1)$, and fraction B $(477 \mathrm{mg})$ with cyclohexane - EtOAc (1:1). Fraction A was purified by preparative HPLC (Hibar RT LiChrosorb RP-18, $7.0 \mu \mathrm{m}$ : column $25 \times 250 \mathrm{~mm}$, flow $15 \mathrm{ml} /$ minute) with a gradient of a decreasing polarity of $0.1 \% \mathrm{H}_{3} \mathrm{PO}_{4}-\mathrm{MeCN}$ as eluent to yield $\mathbf{2 a}(4.2 \mathrm{mg}$, eluted at $48: 52 \mathrm{v} / \mathrm{v})$. Fraction $\mathrm{B}$ upon further purification by Sephadex LH-20 chromatography in $\mathrm{MeOH}$ (column size: $3 \times 30 \mathrm{~cm}$ ) and preparative HPLC (conditions as above) gave rise to $\mathbf{1 a}(5.8 \mathrm{mg}$, eluted at $60: 40 \mathrm{v} / \mathrm{v}), \mathbf{5 a}(1.0 \mathrm{mg}$, eluted at $59: 41 \mathrm{v} / \mathrm{v}), \mathbf{2 c}(6.3 \mathrm{mg}$, eluted at $58: 42 \mathrm{v} / \mathrm{v}), \mathbf{2 d}$ $(3.4 \mathrm{mg}$, eluted at $57: 43 \mathrm{v} / \mathrm{v}), \mathbf{3 b}(2.0 \mathrm{mg}$, eluted at $55: 45$ $\mathrm{v} / \mathrm{v}), \mathbf{3 c}(5.6 \mathrm{mg}$, eluted at $54: 46 \mathrm{v} / \mathrm{v})$, a mixture of $\mathbf{1 b}$ and 1c $(8.5 \mathrm{mg}$, eluted at $49: 51 \mathrm{v} / \mathrm{v}), 8(2.0 \mathrm{mg}$, eluted at $48: 52$ $\mathrm{v} / \mathrm{v}), \mathbf{2 b}(3.3 \mathrm{mg}$, eluted at $47: 53 \mathrm{v} / \mathrm{v}), \mathbf{3 a}(4.2 \mathrm{mg}$, eluted at $44: 56 \mathrm{v} / \mathrm{v}), 7 \mathbf{a}(7.0 \mathrm{mg}$, eluted at $42: 58 \mathrm{v} / \mathrm{v})$, and $7 \mathbf{b}$ $(1.4 \mathrm{mg}$, eluted at $40: 60 \mathrm{v} / \mathrm{v})$. The purity of all isolated compounds as checked by HPLC was $>98 \%$.

Fermentation of Salegentibacter sp. T436 in B2 medium (B1 medium supplemented with corn steep solids $0.5 \%$ ) under the same conditions as above yielded $15.4 \mathrm{~g}$ oily residue from 50 litres of culture fluid. The residue was applied onto a silica gel column $(7 \times 28 \mathrm{~cm})$ and yielded two active fractions: fraction A $(2.35 \mathrm{~g})$ eluted with 
cyclohexane - EtOAc $(3: 1)$ and fraction B (1.1 g) eluted with cyclohexane-EtOAc $(1: 1)$. Chromatography of fraction A on silica gel (column size $5 \times 8.5 \mathrm{~cm}$ ) afforded three active fractions: fraction A1 $(1.29 \mathrm{~g})$ eluted with cyclohexane - EtOAc $(3: 1)$, fraction A2 $(415 \mathrm{mg})$ eluted with cyclohexane-EtOAc $(1: 1)$, and fraction A3 $(467 \mathrm{mg})$ eluted with cyclohexane-EtOAc $(1: 3)$. From fraction A1, 2a (3.0 mg) and 2-nitro-4-(2'-nitroethenyl)-phenol (6, $2.1 \mathrm{mg}$ ) were obtained by Sephadex LH-20 chromatography in $\mathrm{MeOH}$ (column size $3 \times 80 \mathrm{~cm}$ ) and preparative HPLC (Hibar RT LiChrosorb RP-18, $7.0 \mu \mathrm{m}$ : column $25 \times 250 \mathrm{~mm}$, flow $15 \mathrm{ml} /$ minute) with a gradient of a decreasing polarity of $0.1 \% \mathrm{H}_{3} \mathrm{PO}_{4}-\mathrm{MeCN}$. Fraction A2 yielded after the same purification steps $7 \mathbf{b}(1.4 \mathrm{mg}$, eluted at $40: 60 \mathrm{v} / \mathrm{v})$, and $\mathbf{5 b}(1.3 \mathrm{mg}$, eluted at $33: 67 \mathrm{v} / \mathrm{v})$. Fraction A3 by preparative HPLC yielded 1a $(3.7 \mathrm{mg}$, eluted at $60: 40 \mathrm{v} / \mathrm{v}), \mathbf{2 b}(2.2 \mathrm{mg}$, eluted at $47: 53 \mathrm{v} / \mathrm{v})$, and 3b $(1.2 \mathrm{mg}$, eluted at $55: 45 \mathrm{v} / \mathrm{v})$.

Fraction B was further purified by Sephadex LH-20 and preparative HPLC to yield 5c $(5.7 \mathrm{mg}$, eluted at $59: 41 \mathrm{v} / \mathrm{v})$, 4b (2.0 mg, eluted at $44: 56 \mathrm{v} / \mathrm{v})$, and $\mathbf{4 a}(1.4 \mathrm{mg}$, eluted at $32: 68 \mathrm{v} / \mathrm{v})$.

The purity of all compounds as checked by HPLC was $>98 \%$.

\section{Biological Activities}

Antimicrobial activities, determined in the serial dilution assay, and inhibition of germination and growth of Setaria italica and Lepidium sativum were evaluated as described by Anke et al. [9]. Inhibition of conidial germination of Magnaporthe grisea was tested in 96-well microtiter plates following the method of Kettering et al. [10]. Nematicidal activities against Caenorhabditis elegans and Meloidogyne incognita were determined according to Anke et al. [11]. Cytotoxic activity was assayed as described previously [12]. L1210 (mouse lymphocytic leukaemia), Jurkat (human acute $\mathrm{T}$ cell leukaemia), and Colo-320 (human colorectal adenocarcinoma) cells were grown in RPMI 1640 medium. MDA-MB-231 (human breast adenocarcinoma), HL 60 (human promyelocytic leukemia) and MCF-7 (human breast adenocarcinoma) cells were grown in DMEM medium. All media contained 10\% fetal calf serum (FCS), $65 \mu \mathrm{g} / \mathrm{ml}$ of penicillin G and $100 \mu \mathrm{g} / \mathrm{ml}$ of streptomycin sulfate. The cells were incubated at $37^{\circ} \mathrm{C}$ in a humidified atmosphere containing 5.0\% $\mathrm{CO}_{2}$.

Inhibition of DNA, RNA, and protein synthesis was tested with $N$. coryli and HL 60 cells as described previously [12, 13]. Inhibition of oxygen uptake (respiration) in Bacillus subtilis and Nematospora coryli was measured with an oxygen electrode $\left(\mathrm{pO}_{2}\right.$ analysator $\mathrm{R} 55$, Bachofer, Reutlingen). The test substances dissolved in $10 \mu \mathrm{l} \mathrm{MeOH}$ were added to $10^{8} \sim 10^{9}$ cells (control $10 \mu \mathrm{l}$ $\mathrm{MeOH})$.

\section{Results and Discussion}

Strain T436 forms yellow-beige colonies on LB-agar. The cells are Gram-negative ovoid rods, $0.9 \sim 1.1$ (1.4) $\mu \mathrm{m}$ long and $0.7 \sim 0.85 \mu \mathrm{m}$ wide, nonsporogenic, non-motile and aerobic. The strain does not accumulate poly- $\beta$ hydroxybutyrate and has no arginine dihydrolase system. It is oxidase and catalase positive but lacks a $\beta$-galactosidase activity and can reduce nitrate. It is a psychrotolerant strain. The results of the biochemical and physiological characterization are summarized in Table 1.

16S rRNA gene sequence analysis revealed that strain T436 is very closely related to a number of unidentified Arctic sea-ice isolates assigned to the genus Salegentibacter (99\% similarity level), a taxon newly generated by McCammon \& Bowman [14]. As shown in Fig. 1, in which the phylogenetic tree is depicted, the nearest relative was $S$. holothuriorum (98\% similarity level, access no. AB116148). Strain T436 differed from $S$. holothuriorum in the ability to reduce nitrate, its tolerance of high salt concentrations (13\%) and the lack of $\beta$ galactosidase activity. Strain T436 was unable to utilize carbohydrates and did not grow at $37^{\circ} \mathrm{C}$. Therefore, this strain represents a distinct species within the genus Salegentibacter.

Data from a typical fermentation scheme of strain T436 are shown in Fig. 2. The OD reached its maximum after 115 hours, which was in agreement with the number of cfu. The antifungal activity against Nematospora coryli had reached a plateau after 90 hours. Exhaust gas analysis during the fermentation showed a higher rate of carbon dioxide production in comparison to the oxygen consumed indicating an anaerobic like respiration and the utilization of $\mathrm{NO}_{3}^{-}$as an electron acceptor under oxygen limitation (data not shown).

The cultures were harvested after 115 hours. Bioactivity guided fractionation resulted in the isolation of 19 aromatic nitro compounds (Fig. 3). Four of these are new and six were known as synthetic products and are reported here for the first time as natural metabolites (for details see Table 2). All substances were tested for their antimicrobial, nematicidal, phytotoxic, and cytotoxic activities. For comparison the previously reported compounds were also included. The results are given in Tables 3 and 4. 6 showed the highest antimicrobial and cytotoxic activities. Jurakt and L1210 cells were the most sensitive cell lines with an $\mathrm{IC}_{50}$ of $10 \sim 20 \mu \mathrm{g} / \mathrm{ml}$. Though already known as a plant 
Table 1 Biochemical and physiological characteristics of Salegentibacter sp. T436

\begin{tabular}{|c|c|c|c|}
\hline \multicolumn{2}{|c|}{ Characteristic } & \multicolumn{2}{|l|}{ Characteristic } \\
\hline $\mathrm{NaCl}$ requirement & + & Compound as C- \& N-source & \\
\hline Salinity tolerance & $13 \%$ & L-Alanine & + \\
\hline Oxidation/Fermenta & & L-Leucine & - \\
\hline D-Glucose & $-1-$ & L-Proline & + \\
\hline D-Lactose & $-1-$ & D-Aspartic acid & - \\
\hline Sucrose & $-1-$ & L-Lysine & - \\
\hline L-Arabinose & $-1-$ & L-Hystidine & + \\
\hline D-Xylose & $-1-$ & L-Cysteine & - \\
\hline Fructose & $-1-$ & L-Asparagine & - \\
\hline Maltose & $-1-$ & L-Phenylalanine & + \\
\hline Rhamnose & $-1-$ & L-Glutamine & + \\
\hline Mannitol & $-1-$ & L-Tyrosine & - \\
\hline Glycerol & $-1-$ & Hydrolysis of: & \\
\hline Raffinose & $-1-$ & Tween 40, 80 & \pm \\
\hline Sorbitol & $-1-$ & Starch & - \\
\hline \multirow[t]{2}{*}{ D-Galactose } & $-1-$ & Gelatine & + \\
\hline & & Esculin & + \\
\hline \multicolumn{2}{|c|}{ Organic compound as C-source } & Esterase activity & + \\
\hline Sodium acetate & + & Arginine decarboxylase & - \\
\hline D-Glucuronic acid & - & Lysine decarboxylase & - \\
\hline Succinic acid & - & $\beta$-Galactosidase & - \\
\hline Glycine & - & $\mathrm{H}_{2} \mathrm{~S}$ production & - \\
\hline DL-Lactic acid & + & Indole production & - \\
\hline Oxalic acid & - & Nitrate reduction & + \\
\hline Sodium glutamate & + & Motility & - \\
\hline D-Aspartic acid & - & Spore formation & - \\
\hline Sodium pyruvate & + & Poly- $\beta$-hydroxybutyrate & - \\
\hline
\end{tabular}

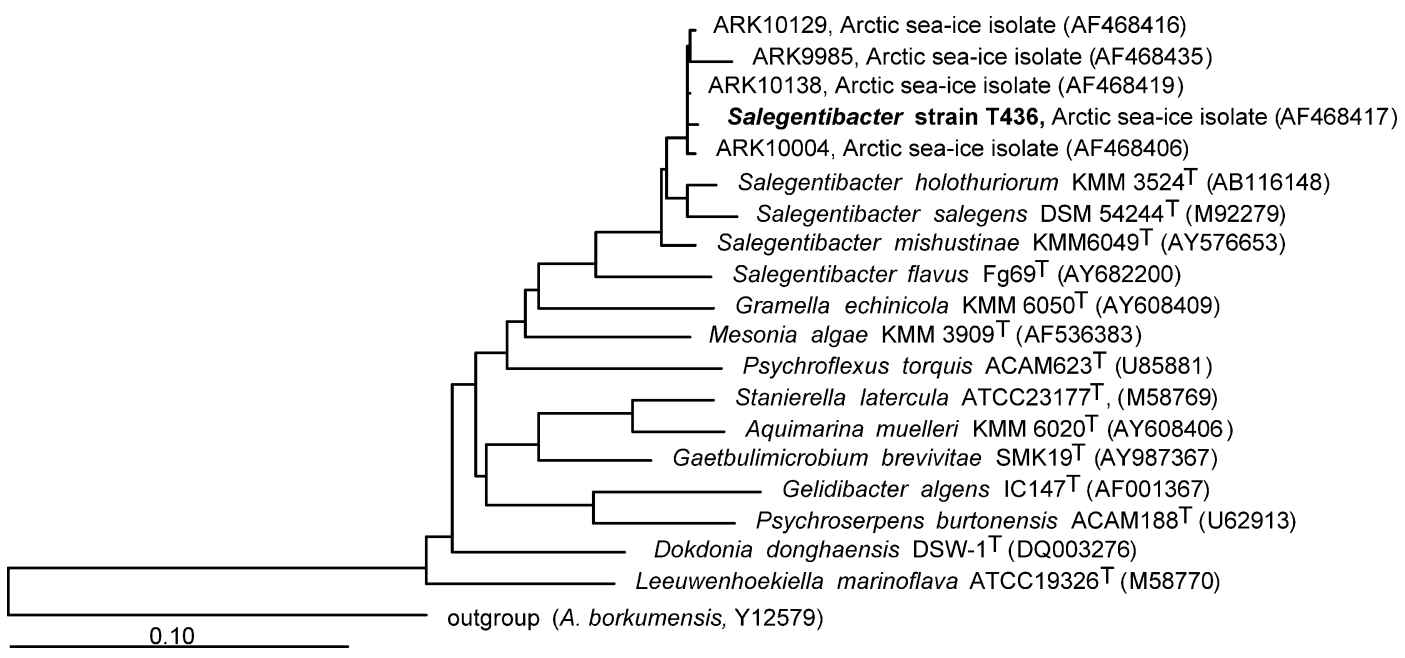

Fig. 1 Phylogenetic tree of strain T436.

Phylogenetic tree reconstructed by using the maximum likelihood algorithm based on the 16S rRNA gene sequence of strain T436 and related members of the Bacteroidetes phylum. The scale bar indicates $10 \%$ estimated sequence divergence. 


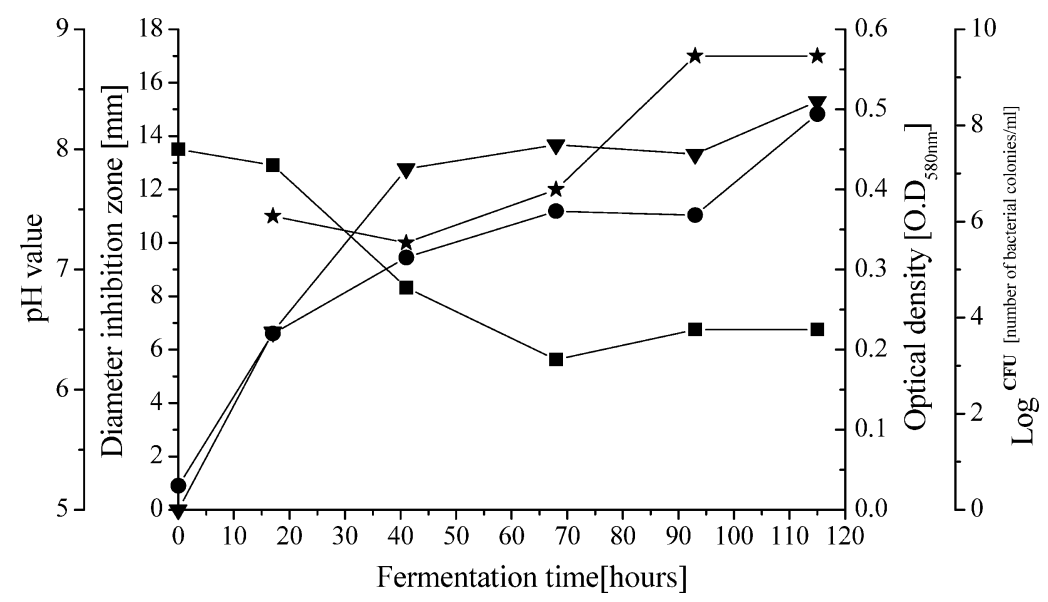

Fig. 2 Fermentation of Salegentibactersp. T436 in 20 liters of B1-medium.

$\star$ Activity against Nematospora coryli, optical density, $\mathbf{V}$ CFU [number of bacterial colonies/ml], $\square \mathrm{pH}$ value.

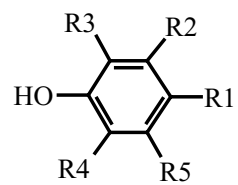

\begin{tabular}{c|ccccc} 
& $\mathrm{R} 1$ & $\mathrm{R} 2$ & $\mathrm{R} 3$ & $\mathrm{R} 4$ & $\mathrm{R} 5$ \\
\hline $\mathbf{1 a}$ & $\mathrm{COOH}$ & $\mathrm{H}$ & $\mathrm{H}$ & $\mathrm{NO}_{2}$ & $\mathrm{H}$ \\
$\mathbf{1 b}$ & $\mathrm{NO}_{2}$ & $\mathrm{H}$ & $\mathrm{NO}_{2}$ & $\mathrm{OCH}_{3}$ & $\mathrm{H}$ \\
$\mathbf{1 c}$ & $\mathrm{NO}_{2}$ & $\mathrm{NO}_{2}$ & $\mathrm{H}$ & $\mathrm{H}$ & $\mathrm{OCH}_{3}$
\end{tabular}<smiles>[R1]C(=O)C([R1])Cc1cc([R9])c(O)c([R3])c1</smiles><smiles>[R]C(=O)Cc1cc([R9])c(O)c([R9])c1</smiles><smiles>[R1]C(=O)CCc1cc([R])c(O)c([R9])c1</smiles>

\begin{tabular}{c|ccc} 
& $\mathrm{R} 1$ & $\mathrm{R} 2$ & $\mathrm{R} 3$ \\
\hline $\mathbf{2 a}$ & $\mathrm{OCH}_{3}$ & $\mathrm{NO}_{2}$ & $\mathrm{H}$ \\
$\mathbf{2 b}$ & $\mathrm{OCH}_{3}$ & $\mathrm{NO}_{2}$ & $\mathrm{NO}_{2}$ \\
$\mathbf{2 c}$ & $\mathrm{OH}$ & $\mathrm{NO}_{2}$ & $\mathrm{H}$ \\
$\mathbf{2 d}$ & $\mathrm{OH}$ & $\mathrm{NO}_{2}$ & $\mathrm{NO}_{2}$
\end{tabular}

\begin{tabular}{c|ccc} 
& $\mathrm{R} 1$ & $\mathrm{R} 2$ & $\mathrm{R} 3$ \\
\hline 3a & $\mathrm{OCH}_{3}$ & $\mathrm{NO}_{2}$ & $\mathrm{NO}_{2}$ \\
$\mathbf{3 b}$ & $\mathrm{OH}$ & $\mathrm{NO}_{2}$ & $\mathrm{H}$ \\
3c & $\mathrm{OH}$ & $\mathrm{NO}_{2}$ & $\mathrm{NO}_{2}$
\end{tabular}<smiles>[R]CCc1cc([R9])c(O)c(CC[Y1])c1</smiles><smiles>O=[N+]([O-])C=Cc1ccc(O)c([N+](=O)[O-])c1</smiles><smiles>[R]c1cc(-c2coc3cc(O)cc(O)c3c2=O)cc([N+](=O)[O-])c1O</smiles><smiles>O=[N+]([O-])c1c[nH]c2ccccc12</smiles>

Fig. 3 Structures of the aromatic nitro compounds from Salegentibacter sp. T436.

metabolite, this compound has not previously been evaluated for biological activities [15]. The antimicrobial and cytotoxic activities of $\mathbf{6}$ are probably the result of an inhibition of respiration, for example in N. coryli, a $50 \%$ inhibition of oxygen consumption was observed at $3.6 \mu \mathrm{g} / \mathrm{ml}$. This is in accordance with a nonselective inhibition of incorporation of precursors into DNA, RNA and protein. The concentrations for a $50 \%$ inhibition were 
Table 2 Compounds from Salegentibacter sp. T436

\begin{tabular}{clcc}
\hline Compound & \multicolumn{1}{c}{ Chemical name } & Note & \multicolumn{2}{c}{ Reference $^{\text {a }}$} \\
\hline $\mathbf{1 a}$ & 4-Hydroxy-3-nitrobenzoic acid & $\mathrm{S}$ & 30 \\
$\mathbf{1 b}$ & 4,6-Dinitroguiacol & $\mathrm{K}$ & 28 \\
$\mathbf{1 c}$ & 4,5-Dinitro-3-methoxyphenol & $\mathrm{K}$ & 28 \\
$\mathbf{2 a}$ & (4-Hydroxy-3-nitrophenyl)-acetic acid methyl ester & $\mathrm{K}$ & 27 \\
$\mathbf{2 b}$ & (4-Hydroxy-3,5-dinitrophenyl)-acetic acid methyl ester & $\mathrm{S}$ & Commercial \\
$\mathbf{2 c}$ & (4-Hydroxy-3-nitrophenyl)-acetic acid & $\mathrm{K}$ & 29 \\
$\mathbf{2 d}$ & (4-Hydroxy-3,5-dinitrophenyl)-acetic acid & $\mathrm{S}$ & Commercial \\
$\mathbf{3 a}$ & (4-Hydroxy-3,5-dinitrophenyl)-propionic acid methyl ester & $\mathrm{N}$ & - \\
$\mathbf{3 b}$ & (4-Hydroxy-3-nitrophenyl)-propionic acid & $\mathrm{K}$ & 29 \\
$\mathbf{3 c}$ & (4-Hydroxy-3,5-dinitrophenyl)-propionic acid & $\mathrm{S}$ & Commercial \\
$\mathbf{4 a}$ & 2-Chloro-3-(4-hydroxy-3,5-dinitrophenyl)-propionic acid methyl ester & $\mathrm{N}$ & - \\
$\mathbf{4 b}$ & 2-Hydroxy-3-(4-hydroxy-3-nitrophenyl)-propionic acid methyl ester & $\mathrm{N}$ & - \\
$\mathbf{5 a}$ & 2-(4-Hydroxy-3-nitrophenyl)-ethanol & $\mathrm{K}$ & 27 \\
$\mathbf{5 b}$ & 2-(4-Hydroxy-3,5-dinitrophenyl)-ethyl chloride & $\mathrm{N}$ & - \\
$\mathbf{5 c}$ & 2-(4-Hydroxy-3,5-dinitrophenyl)-ethanol & $\mathrm{S}$ & Commercial \\
$\mathbf{6}$ & 2-Nitro-4-(2'-nitroethenyl)-phenol & $\mathrm{K}$ & 15 \\
$\mathbf{7 a}$ & 3',5'-Dinitrogenistein & $\mathrm{K}$ & 26 \\
$\mathbf{7 b}$ & 3'-Nitrogenistein & $\mathrm{K}$ & 26 \\
$\mathbf{8}$ & 3-Nitro-1H-indole & $\mathrm{S}$ & 31 \\
\hline
\end{tabular}

${ }^{a}$ S: known as synthetic compound (not from natural source), K: known as natural substance, N: new compound.

Table 3 Antimicrobial activity of metabolites from Salegentibacter sp. T436 in the serial dilution assay

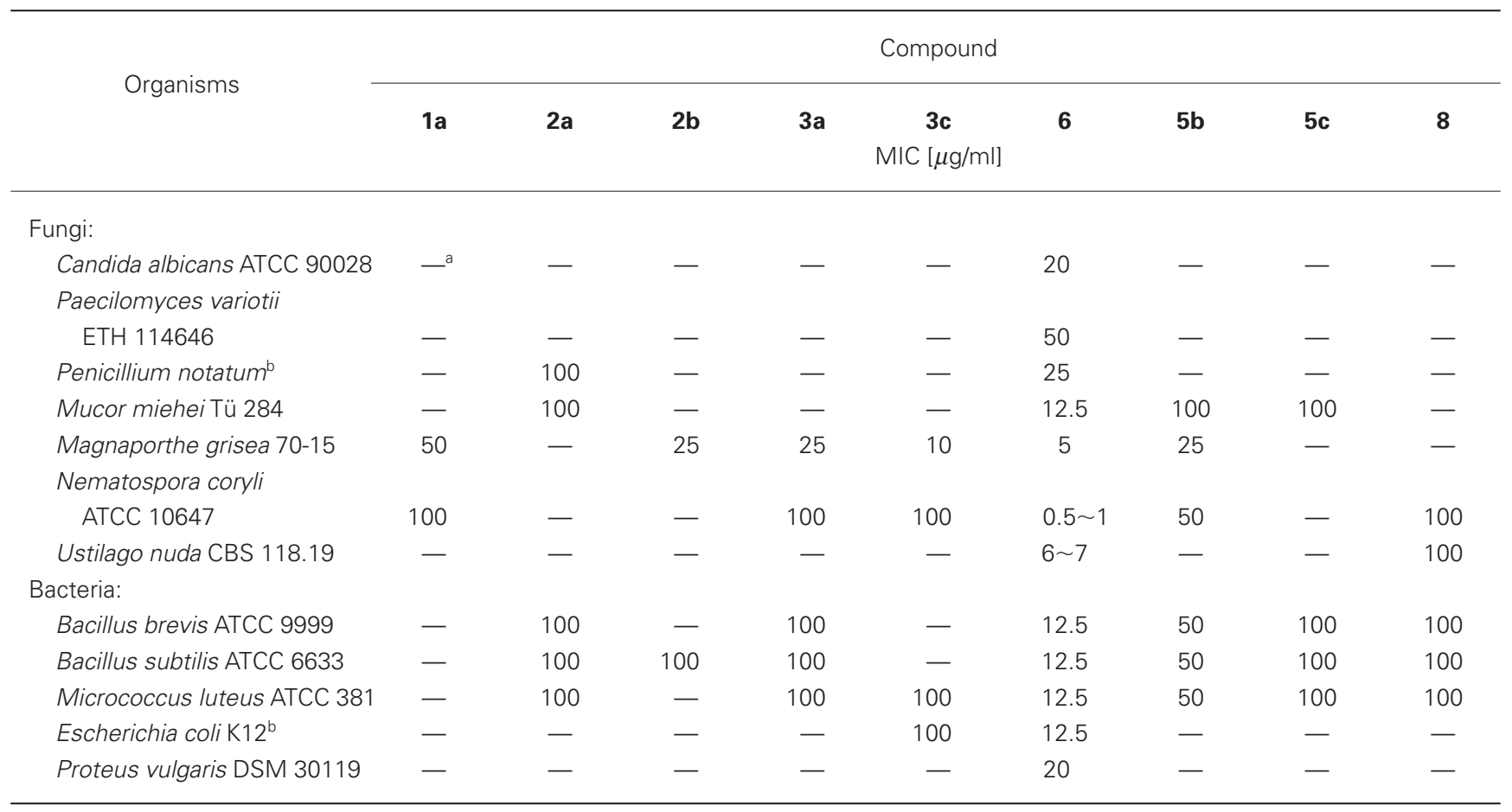

a - not active at $100 \mu \mathrm{g} / \mathrm{ml}$, b strains from the collection of the IBWF. 
Table 4 Cytotoxic activities of the metabolites from Salegentibacter sp. T436

\begin{tabular}{|c|c|c|c|c|c|c|c|}
\hline \multirow{3}{*}{ Cell line } & \multicolumn{7}{|c|}{ Compound } \\
\hline & 2c & $3 a$ & $3 c$ & $5 b$ & 6 & $7 b$ & 8 \\
\hline & \multicolumn{7}{|c|}{$I_{50}[\mu \mathrm{g} / \mathrm{ml}]$} \\
\hline L1210 ATCC CCL 219 & 100 & 100 & $>100$ & 80 & 20 & 50 & $>100$ \\
\hline Jurkat DSMZ ACC 282 & $>100$ & $>100$ & 60 & $>100$ & 10 & 60 & $>100$ \\
\hline MDA-MB-321 ATCC HTB-26 & $>100$ & $>100$ & $>100$ & $>100$ & 30 & $>100$ & 100 \\
\hline MCF-7 DSMZ ACC 115 & $>100$ & $>100$ & $>100$ & $>100$ & $>100$ & $>100$ & $>100$ \\
\hline Colo-320 DSMZ ACC 144 & $>100$ & $>100$ & $>100$ & 80 & 17 & $>100$ & $>100$ \\
\hline
\end{tabular}

$2.8 \mu \mathrm{g} / \mathrm{ml}$ for DNA and RNA and $3.4 \mu \mathrm{g} / \mathrm{ml}$ for protein synthesis.

The structurally closely related $\beta$-nitrostyrene SL-1, isolated from Streptomyces lavendulae [16] showed moderate antibacterial activity, and antifungal activity restricted towards some Trichophyton species (MIC $12.5 \sim 25 \mu \mathrm{g} / \mathrm{ml}$ ) [17]. Moreover, SL-1 was cytotoxic for L1210 cells with $\mathrm{IC}_{50}$ value of $1.0 \mu \mathrm{g} / \mathrm{ml}$. Comparison of the biological activities of 6 with those of SL- 1 indicates that presence of a second nitro group on the phenyl ring enhances the antimicrobial activity but reduces its cytotoxic effect.

The novel compounds $\mathbf{4 a}$ and $\mathbf{4 b}$ were not active in any test system up to $100 \mu \mathrm{g} / \mathrm{ml}$. Compounds $\mathbf{3 a}$ and $\mathbf{5 b}$ showed only very weak antimicrobial activities. Among the isolated compounds, only the mixture of $\mathbf{1 b}$ and $\mathbf{1 c}$ showed moderate nematicidal activity against $M$. incognita with a $\mathrm{LD}_{90}$ value of $25 \mu \mathrm{g} / \mathrm{ml}$.

Most of the nitro-aromatic compounds were phytotoxic starting at $70 \mu \mathrm{g} / \mathrm{ml}$. Although 1a was phytotoxic at a higher concentration $(300 \mu \mathrm{g} / \mathrm{ml})$, it promoted the growth of roots and shoots at lower concentration but inhibited the development of chloroplasts. Similar results were also obtained during a previous study on nitro-benzoate derivatives [18]. The presence of a nitro group in 3-position and a hydroxyl group in 4-position was essential for the phytotoxic activity of these compounds regardless of the side chain in the 1-position [18]. Our tests revealed that the presence of a second nitro group on the aromatic ring decreases the phytotoxic activities (data not shown).

A number of antibiotics bearing nitro groups were reported from bacteria, such as chloramphenicol [19] and pyrrolnitrin [20]. Aromatic nitro compounds are rare structural elements in nature [21] and their synthesis is not fully understood. Several biosynthetic pathways were proposed. One possibility is the direct nitration of aromatic compounds in the presence of $\mathrm{KNO}_{3}$ in the medium [22] or by enzymatic oxidation of the amino groups [23]. Nitration can also be the result of peroxynitrite dependent or independent pathways [24, 25].

Acknowledgements We thank the DAAD, Bonn (German Academic Exchange Service) and the Federal Minister for Science and Technology (BMBF, Berlin-Bonn) for financial support. The expert technical assistance of W. Schuck and S. Paul is gratefully acknowledged.

\section{References}

1. Fenical W. Chemical studies of marine bacteria: developing a new resource. Chem Rev 93: 1673-1683 (1993)

2. Laatsch H. Marine bacterial metabolites. In Frontiers in MarineBiotechnology. Ed. P. Proksch et al., pp. 225-288, Horizon Bioscience, Norfolk (2006)

3. Schuhmann I. Aufbau einer HPLC-UV-ESI-MS/MSDatenbank und ihre Anwendung im Screening arktischer und antarktischer Meeresbakterien. PhD Thesis University of Göttingen 2005 and Schuhmann I, Al-Zereini W, Anke H, Laatsch H. New aromatic nitro compounds from Salegentibacter sp. T436. II. Physico-chemical properties and structure determination. In preparation

4. Brinkmeyer R, Knittel K, Jürgens J, Weyland H, Amann R, Helmke E. Diversity and structure of bacterial communities in Arctic versus Antarctic pack ice. Appl Environ Microbiol 69: 6610-6619 (2003)

5. Baumann L, Baumann P, Mandel M, Allen RD. Taxonomy of aerobic marine eubacteria. J Bacteriol 110: 402-429 (1972)

6. Süßmuth R, Eberspächer J, Haag R, Springer W. Mikrobiologisch-biochemisches Praktikum. Georg Thieme Verlag, Stuttgart (1999)

7. Helmke E, Weyland H. Rhodococcus marinonascens sp. nov., an actinomycete from the sea. Int J Syst Bacteriol 34: 
127-138 (1984)

8. Sambrook J, Fritsch EF, Maniatis T. Molecular cloning: a laboratory manual. Cold Spring Harbor Laboratory Press. 3rd edition (2001)

9. Anke H, Bergendorff O, Sterner O. Assay of the biological activities of guaiane sesquiterpenoids isolated from the fruit bodies of edible Lactarius species. Food Chem Toxicol 27: 393-398 (1989)

10. Kettering M, Valdivia C, Sterner O, Anke H, Thines E. Heptemerones $\mathrm{A} \sim \mathrm{G}$, seven novel diterpenoids from Coprinus heptemerus: Producing organism, fermentation, isolation and biological activities. J Antibiot 58: 390-396 (2005)

11. Anke H, Stadler M, Mayer A, Sterner O. Secondary metabolites with nematicidal and antimicrobial activity from nematophagous fungi and Ascomycetes. Can J Bot 73: 932-939 (1995)

12. Zapf S, Hossfeld M, Anke H, Velten R, Steglich W. Darlucin $\mathrm{A}$ and B, new isocyanide antibiotics from Sphaerellopsis filum (Darluca filum). J Antibiot 48: 36-41 (1995)

13. Mierau V, Anke T, Sterner O. Dacrymenone and VM 3298$2-$ new antibiotics with antibacterial and antifungal activity. Z Naturforsch 58c: 541-546 (2003)

14. McCammon SA, Bowman JP. Taxonomy of the Antarctic Flavobacterium species: description of Flavobacterium gillisiae sp. nov., Flavobacterium tegetincola sp. nov., and Flavobacterium xanthum sp. nov., nom. rev. and reclassification of [Flavobacterium] salegens as Salegentibacter salegens gen. nov., comb. nov. Int J Syst Evol Microbiol 50: 1055-1063 (2000)

15. Bose AK, Urbanczyk-Lipkowska Z, Subbaraju GV, Manhas MS, Ganguly SN. An unusual secondary metabolite from an Indian mangrove plant, Sonneratia acida Linn. F. pp. 402-411, Oceanography of the Indian Ocean. Desai, B.N. (ed.). A.A. Balkema, Rotterdam, Netherlands (1992)

16. Mikami Y, Takahashi K, Fukushima K, Yazawa K, Arai T. A new pigment from Streptomyces lavendulae. J Antibiot 40: 385-387 (1987)

17. Mikami Y, Yazawa K, Maeda A, Uno J. Antifungal activity of SL-1, a $\beta$-nitrostyrene type pigment and its synthetic congeners. J Antibiot 44: 1454-1456 (1991)

18. Price DN, Wain RL. Studies on plant growth-regulating substances. XLI. Structure-activity relationships and metabolism of a group of nitrophenols capable of inhibiting chloroplast development. Ann Appl Biol 83: 115-124 (1976)

19. Rebstock MC, Crooks HM, Controulis J, Bartz QR.
Chloramphenicol (chloromycetin). IV. Chemical studies. J Am Chem Soc 71: 2458-2462 (1949)

20. Arima K, Imanaka H, Kousaka M, Fukuta A, Tamura J. Pyrrolnitrin, a new antibiotic substance produced by Pseudomonas. J Agric Biol Chem 24: 575-576 (1964)

21. Winkler R, Hertweck C. Sequential enzymatic oxidation of aminoarenes to nitroarenes via hydroxylamines. Angew Chem Int Ed 44: 4083-4087 (2005)

22. Carter GT, Nietsche JA, Goodman JJ, Torrey MJ, Dunne TS, Siegel MM, Borders DB. Direct biochemical nitration in the biosynthesis of dioxapyrrolomycin. A unique mechanism for the introduction of nitro groups in microbial products. J Chem Soc, Chem Commun: 1271-1273 (1989)

23. Kirner S, van Pée K-H. Biosynthese von Nitroverbindungen: Die enzymatische Oxidation einer Vorstufe mit Aminogruppe zu Pyrrolnitrin. Angew Chem 106: 346-347 (1994)

24. Kono Y, Yamasaki T, Ueda A, Shibata H. Catalase catalyses of peroxynitrite-mediated phenolic nitration. Biosci Biotechnol Biochem 62: 448-452 (1998)

25. Sakihama Y, Tamaki R, Shimoji H, Ichiba T, Fukush Y, Tahara S, Yamasaki H. Enzymatic nitration of phytophenolics: evidence for peroxynitrite-independent nitration of plant secondary metabolites. FEBS Lett 553: 377-380 (2003)

26. Shangguan D, Rong J, Baoyi L, Chunling X, Jianbo W. Production, isolation and structure elucidation of novel isoflavonoid compound K3-D4, K3-D5, K3-D6. Zhongguo Kangshengsu Zazhi 24: 254-257 (1999)

27. Sviridov SI, Ermolinskii BS. Secondary metabolites of Pyricularia oryzae. I. $O$-nitrophenol derivatives. Khimiya Prirodnykh Soedinenii 6: 811-818 (1990)

28. Ohta K. Chemical studies on biologically active substances in seaweeds. Proceedings-International Seaweed Symposium 9: 401-411 (1979)

29. Zhang H, Jin W-Z, Wang YB. Isolation and identification of

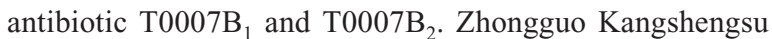
Zazhi 15: 321-324 (1990)

30. Bose AK, Ganguly SN, Manhas MS, Rao S, Speck J, Pekelny U, Pombo-Villars E. Microwave promoted rapid nitration of phenolic compounds with calcium nitrate. Tetrahedron Lett 47: 1885-1888 (2006)

31. Berti G, Da Settimo A, Nannipieri E. The reactions of some indole derivatives with benzoyl nitrate. Novel oxidative coupling reactions of 2-methylindoles. J Chem Soc C: 2145-3151 (1968) 